\title{
Mendulang Mutiara Kata: Identifikasi dan Intertektualitas Ekspresi Kearifan Lokal Dalam Sastra Bali Modern
}

\author{
I Nyoman Darma Putra ${ }^{1}$, Ida Ayu Laksmita Sari ${ }^{2}$ \\ ${ }^{1}$ Prodi Sastra Indonesia, Fakultas Ilmu Budaya, Universitas Udayana, \\ Jalan Nias 13 Denpasar Bali 80114, Indonesia \\ ${ }^{2}$ Prodi Sastra Jepang, Fakultas Ilmu Budaya, Universitas Udayana, \\ Jalan Nias 13 Denpasar, Bali 80114, Indonesia \\ 'idarmaputra@yahoo.com
}

Banyak ungkapan terkenal di masyarakat yang asal-usulnya kurang diketahui oleh publik, padahal ungkapan itu berasal dari karya seni seperti lagu atau karya sastra. Ungkapan-ungkapan seperti "jaen hidup di Bali" (enak hidup di Bali), "sakadi ngurug pasih" (ibarat menimbun samudera), "gede ombak gede angin" (ombak besar angin kencang), dan "tresnane ajur lebur satonden kembang" (kasih layu sebelum berkembang) adalah ekspresi kearifan lokal Bali yang bisa dirunut jejaknya lewat karya sastra. Artikel ini bertujuan untuk mendulang, menggali, mengumpulkan, dan menganalisis kata-kata mutiara yang terkandung dalam sastra Bali modern. Data yang terkumpul dianalisis dengan intertekstualitas untuk melihat hubungan antara ungkapan dalam sastra dan dalam sumber lainnya serta perbedaan makna kontekstualnya. Hasil analisis menunjukkan ada tujuh jenis kata-kata mutiara yang banyak muncul dalam karya sastra Bali modern, yaitu sesonggan (pepatah), sesawangan (perumpamaan), seloka (bidal), wawangsalan, sesimbing, peparikan, dan bladbadan. Dari ketujuh bentuk itu, sesonggan (pepatah) yang paling banyak muncul karena paling efektif untuk menyampaikan ungkapan secara tidak langsung.

Kata kunci: sastra bali modern, kearifan lokal, kata-kata mutiara, intertekstualitas

\section{Mining Pearl of Words: Identifying and Intertextuality of Expression of Local Wisdom in Modern Balinese Literature}

Many well-known expressions in the community whose origins are less known to the public, even though the expression comes from works of art such as songs or literary works. Expressions such as "jaen hidup di Bali" (life is good in Bali), "sakadi ngurug pasih" (like hoard ocean), "gede ombak gede angin" (big waves of strong winds), and "tresnane ajur lebur satonden kembang" (love withered before blooming) is the expression of Balinese local wisdom that can be traced to their tracks through literary works. This article aims to identify, explore, collect and analyze the aphorisms contained in modern Balinese literature. This is a qualitative study whose data is taken from research samples in the form of short stories of modern literature written in the Balinese language. The collected data is analyzed by intertextuality to see the relationship between expressions in literary texts and in other sources along with their different contextual meanings. The analysis shows that there are seven types of aphorisms that appear in modern Balinese literatury texts, namely sesonggan, sesawangan, seloka, wawangsalan, sesimbing, peparikan, and bladbadan. Out of seven, the sesawangan (proverb) is widely used as it is effective in articulating expression indirectly.

Keywords: modern balinese literature, local wisdom, proverbs, intertextuality

Proses Review : 1 - 18 April 2019, Dinyatakan Lolos: 22 April 2019 


\section{PENDAHULUAN}

Banyak ungkapan atau ekspresi kearifan lokal dalam bahasa Bali yang terkenal tetapi asal-usulnya kurang diketahui oleh masyarakat. Misalnya ungkapan 'karang awake tandurin' atau 'nandurin karang awak' ('bertani dalam raga sendiri' atau 'meningkatkan potensi diri'). Ungkapan ini berasal dari puisi tradisional berbahasa Bali berjudul $G e$ guritan Salampah Laku karya Ida Pedanda Made Sidemen dari Sanur (Agastia 1994). Geguritan ini jarang diketahui masyarakat, kalah populer dengan ungkapan indah yang dihasilkannya. Contoh lain adalah ungkapan 'sane telas tunas tityang' (yang habis yang saya minta), jauh lebih dikenal dari puisi Geguritan Tamtam yang memuatnya. Barangkali tidak banyak yang tahu bahwa ungkapan 'eda ngaden awak bisa, depang anake ngadanin' (jangan menganggap diri bisa, biar orang lain yang menilai) berasal dari Geguritan Basur. Lagu pop Bali juga banyak menggunakan peribahasa Bali sebagai judul atau sisipan dalam lirik, seperti lagu berjudul "Magantung Bok Akatih" (Bergantung di Sehelai Rambut) yang dinyanyikan oleh Nanoe Biroe dan "Medamar di Abing" (Berlampu di Tebing) oleh De Pengkung (Turaeni 2017)

Jikapun ungkapan itu diketahui berasal dari karya seni, seperti lagu pop Bali atau karya sastra, ungkapan itu lebih terkenal daripada karya seni atau karya sastra yang menjadi sumbernya. Ada dua pandangan mengenai fenomena di atas. Pertama, pandangan yang menganggap tidak masalah seandainya masyarakat tidak mengetahui asal-usul ungkapan yang diketahuinya, yang penting mereka mengetahui ungkapan itu. Dengan diketahuinya ungkapan itu, karya sastra sudah melakukan salah satu tugas sosialnya, yakni menyediakan ungkapan kearifan lokal bagi amsyarakat untuk berekspresi. Kedua, pandangan yang menganggap bahwa masyarakat yang menggunakan kearifan lokal untuk berekspresi idealnya mengetahui karya sastra yang menjadi sumbernya karena dengan demikian karya sastra itu juga akan sama terkenalnya dengan ungkapan yang dihasilkan. Untuk ini, diperlukan usaha-usaha untuk memperkenalkan karya sastra melalui ekspresi kearifan lokal yang dihasilkan.

Artikel ini menggali dan memaknai ekspresi kearifan lokal dalam sastra Bali modern. Yang dimaksudkan dengan ekspresi kearifan lokal adalah ungkapan-ungkapan khusus dalam teks sastra. Bahasa Bali kaya akan peribahasa, seperti sesinggan, cecimpedan, bladbadan, seloka, raos ngempelin, sesimbing (Ginarsa, 1984; Bagus, 1979/1980; Tinggen, 1988). Hal itu banyak digunakan dalam atau berasal dari karya seni termasuk lagu pop Bali dan karya sastra. Dalam artikel ini, penggalian dilakukan dengan mengidentifikasi dan mencatatnya, sedang pemaknaan dilakukan dengan dua cara yaitu pemaknaan tekstual dari konteks teks yang memuatnya, dan pemaknaan dari konteks sosial yaitu berdasarkan pemakaiannya di masyarakat. Penggalian, pemaknaan, dan pengenalan ungkapan-ungkapan kearifan lokal merupakan jalan untuk memperkenalkan karya sastra sumbernya.

\section{TINJAUAN PUSTAKA}

Penelitian terhadap ungkapan, peribahasa, atau kearifan lokal Bali mulai mendapat perhatian para sarjana. Ada dua penelitian yang patut dicatat yaitu yang meneliti penggunaan peribahasa basa Bali dalam lagu pop Bali (Turaeni 2017) dan Putra dkk (2016). Objek kajian penelitian mereka adalah ranah lagu pop Bali, sedangkan kajian artikel ini menggali dan mengidentifikasi penggunaan peribahasa Bali dalam karya sastra Bali modern. Meskipun berbeda, kedua penelitian sebelumnya memberikan informasi mengenai kian bergairahnya penggunaan peribahasa Bali dalam dunia kesenian, khususnya lagu pop Bali.

Turaeni (2017) dalam penelitiannya berjudul "Pengalihwahanaan Paribasa Bali Lisan ke dalam Lagu Bali Populer" menunjukkan banyak sekali lagu pop Bali yang menggunakan ungkapan dari peribahasa Bali. Ungkapan tersebut ada yang dipakai dalam judul ada pula dalam lirik lagu, seperti mejempong bebek (Gus Babah), madamar di langit, ogel-ogel ikuh celeng (Yong Sagita); lemete sing nyidaang ngelung (A.A. Raka Sidan), megantung bok akatih (Nanoe Biroe); kalem sambuk (Dek Ulik), layah tanpa tulang (Trio Kirani) (Turaeni, 2017:212). Usaha kreatif menyisipkan peribahasa Bali ke dalam lagu pop itu, menurut Turaeni, adalah untuk memperkuat roh dan jati diri lagu pop Bali. Dalam simpulannya, dia menyebutkan bahwa penggunaan peribahasa Bali dalam lagu itu selain merupakan pendokumentasian peribahasa juga untuk aktualisasi nilai-nilai kearifan lokal dalam wahana lagu pop Bali (Turaeni, 2017:223).

Putra dkk (2016) dalam artikel "Basita Paribasa ring Album "Nasi Goreng Spesial" Kekawian Widi Widiana" menggali ungkapan peribahasa Bali yang terdapat dalam satu album lagu. Kalau penelitian Turaeni meneliti ungkapan kearifan lokal Bali dalam sejumlah lagu, Putra dkk melakukannya sebatas dalam album pop Bali karya Widi Widiana, salah satu penyanyi pop Bali papan atas. Dalam identifikasi itu, mereka menemukan enam jenis peribahasa yang banyak muncul, yaitu (a) sasemon, (b) cecangkitan, (c) sesawangan, (d) wewangsalan, (e) peparikan, dan (f) pepindan. Ulasan Putra dkk kurang memberikan contoh dari teks lagu peribahasa yang dimaksud, hanya satu kutipan lagu yang ditunjukkan sebagai contoh peribahasa Bali yang sudah disesuaikan dengan perkembangan zaman yaitu ungkapan "formalin sik Luh, Pang awet cinta iraga" (dengan satu formalin sayang, awet cinta kita).

Seperti apa penggunaan ungkapan bahasa Bali dalam sastra Bali modern menjadi fokus penelitian ini. Dalam konteks penelitian sastra Bali modern, kajian terhadap identifikasi dan pemaknaan peribahasa di dalamnya belum pernah dilakukan. Selama ini, kehadiran sastra Bali modern sudah 
lebih dari satu abad, penelitian terhadap jenis karya sastra ini masih terbatas sekali. Jika dilihat kajian atas sastra Bali modern, memang kebanyakan berupa skripsi atau tesis yang dikerjakan mahasiswa. Penulisan berupa buku bisa dihitung dengan jari, misalnya Wayan Jendra menulis artikel "Sekilas Tentang Puisi sastra Bali Modern" (1976), Bagus dan Ginarsa menerbitkan buku Kembang Rampe Kasusastraan Bali (1978), dan Tusthi Eddy menulis buku Mengenal Sastra Bali Modern (1991). Kajian-kajian tersebut memberikan pengetahuan dasar umum mengenai keberadaan dan sedikit mengenai sejarah sastra Bali modern. Buku Kembang Rampe Kasusastraan Bali, sesuai judulnya, berisi daftar karya sastra seperti puisi, cerita pendek, dan drama. Analisis kritis tidak disertai dalam buku ini.

Buku Mengenal Sastra Bali Modern (1991) karya Tusthi Eddy berisi sejarah dan sedikit pengenalan karya sastra Bali modern, mulai dari kelahiran novel Nemu Karma (1931) karya Wayan Gobiah. Tusthi Eddy tidak melakukan survey dan analisis kritis atas karya yang ada. Buku ini bagus sebagai pengenalan bagi pembaca yang ingin tahu mengenai sastra Bali modern serta para pengarang dan karya-karya yang mereka tulis.

Sejalan dengan perkembangan waktu, sejalan dengan bertambahnya karya yang terbit, muncullah kemudian buku Tonggak Baru Sastra Bali Modern (2010 [2000]) karya Darma Putra. Buku ini memberikan perspektif baru akan masa kelahiran sastra Bali modern, dari biasanya disebutkan lahir tahun 1931 dengan menggunakan novel Nemu Karma karya Wayan Gobiah, diajukan Putra (2010; 2013) tahun 1910-an karena sudah ada karya sastra terbit berupa cerita pendek tahun 1913. Selain menawarkan tonggak baru untuk kelahiran sastra Bali modern, buku Tonggak Baru Sastra Bali Modern ini juga memberikan analisis terhadap kecenderungan tematik karya-karya.

Penelitian mengenai ungkapan kata mutiara dalam karya sastra Bali modern belum pernah dilaksanakan, dengan demikian penelitian ini termasuk orisinal. Kalau penelitian sebelumnya diarahkan pada sejarah sastra Bali modern, analisis tema dan nilai-nilai, kajian ini memberikan perhatian khusus dalam mengidentifikasi dan memaknai kata-kata mutiara dalam sastra Bali modern.

\section{DATA, TEORI, METODE}

Penelitian ini merupakan kajian kualitatif. Data utamanya diambil dari karya sastra berupa cerita pendek. Dipilih lima buku kumpulan cerita pendek yang mewakili generasi kepengarangan, yaitu generasi tua yang mulai berkarya tahun 1970-an, generasi peralihan yang mulia berkarya 1990-an/2000-an, dan generasi muda yang karyanya muncul tahun 2010-an.

Kelima antologi cerpen mereka adalah Katemu Ring Tampaksiring ('Bertemu di Tampaksiring', 1974 [2004]) karya

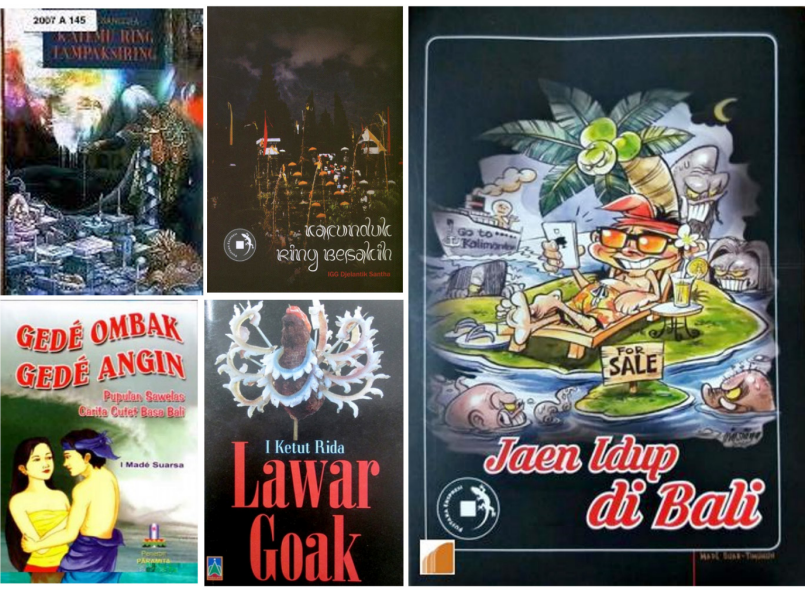

Gambar 1. Sampul buku cerpen yang dijadikan sumber data.

I Made Sanggra, Lawar Goak ('Lawar Gagak', 2014) karya I Ketut Rida, Gde Ombak Gde Angin ('Besar Ombak, Besar Angin', 2006) karya I Made Suarsa, Kacunduk ring Besakih ('Bertemu di Besakih', 2015) karya IGG Djelantik Santha, dan Jaen Idup di Bali ('Enak Hidup di Bali', 2016) karya Made Suar Timuhun (Lihat Gambar 1). Dalam penelitian ini, terdapat sekitar 75 cerita, data yang dianggap cukup untuk penelitian awal. Semua cerita itu dibaca, kemudian kata-kata mutiara di dalamnya diidentifikasi, dicatat konteks tekstual, dan konteks sosialnya.

Kajian menggunakan teori intertekstualitas yang diperkenalkan oleh kritikus Perancis, Julia Kristeva, tahun 1960an. Dalam menyusun teori intertekstualitas, Kristeva mendapat inspirasi dari filosof dari Rusia Mikhail Bakhtin (1895-1975), yang berpendapat bahwa makna tidak dapat dilihat sebagai produk akhir ('meaning cannot be "viewed as a finished product"” ") (Tryniecka 2014: 154). Ini berarti bahwa makna teks dapat terus berubah. Perubahan makna tersebut sesuai dengan pendapat Tryniecka yang mengatakan bahwa teori intertextualitas "strictly dependent upon historical and temporal processes" (2014:156), artinya bahwa 'secara pasti tergantung pada sejarah dan proses kewaktuan'. Dengan kata lain, konteks sejarah dan waktu sangat ikut menentukan makna sebuah teks.

Teori intertekstualitas dikembangkan oleh beberapa sarjana. Graham Allen, misalnya, dalam bukunya Intertextuality (2000) menjelaskan bahwa:

Texts, whether they be literary or non-literary, are viewed by modern theorists as lacking in any kind of independent meaning. They are what theorists now call intertextual (2001:1).

\section{Artinya:}

Teks, apakah itu teks sastra atau bukan-sastra, dilihat oleh penganut teori modern kurang memiliki makna independen. Itulah yang disebutkan oleh penganut teori modern sebagai intertextual. 
Pernyataan di atas menegaskan bahwa makna sebuah teks menurut penganut teori modern tidaklah independen, tidak bebas, tetapi maknanya tergantung dari teks-teks yang lain yang digunakan untuk membacanya. Selain itu, seperti ditegaskan di atas, konteks sejarah dan waktu juga ikut menentukan makna teks.

Bibit intertektualitas tercermin dalam esai Barthes (1977) yang berjudul 'The Death of the Author'. Bagi Barthes, makna sastra tidak pernah sepenuhnya bisa distabilkan oleh pembaca mengingat hubungan intertekstual karya sastra selalu mengarahkan pembaca kepada hubungan intertekstual yang baru (Allen 2000:3). Pembacaan teks dengan teks baru, perspektif baru, tafsir baru akan selalu memberikan makna baru. Makna teks tidak bisa lagi dicari dari kesadaran pengarang. Konsep kematian pengarang dari Barthes menghancurkan konsepp 'the myth of affiliation', yang menolak gagasan bahwa makna datang dari atau milik dari pengarang (Allen 2003:47; Tryniecka 2014: 154).

Teori intertekstualitas digunakan untuk memberikan makna ungkapan kearifan lokal dalam teks dengan yang ada di luar teks atau dalam pemakaiannya di masyarakat. Metode kerja penelitian diawali dengan pembacaan cerita secara berulang, identifikasi ungkapan kata-kata mutiara, kategorisasi sesuai dengan gaya bahasa yang ada dalam bahasa Bali, kemudian pemaknaan tekstual dan intertekstualitas. Pemaknaan intertekstual dilakukan dengan memperhatikan konteks sosial dan konteks sejarah karya sastra.

Pembacaan berulang atas kelima antologi cerita pendek yang menjadi objek penelitian ini menemukan 42 kata-kata Mutiara (Lihat Tabel 1).-

Tabel 1. Ungkapan, Arti, dan Jenis dari Sastra Bali Modern

\begin{tabular}{llll}
\hline No & $\begin{array}{l}\text { Ungkapan, } \\
\text { Sumber }\end{array}$ & Arti Ungkapan & $\begin{array}{l}\text { Jenis } \\
\text { ungkapan }\end{array}$ \\
\hline 1 & $\begin{array}{l}\text { munjuk benang } \\
\text { tuna aji } \\
\text { (Sanggra, } \\
\text { 2004:28) }\end{array}$ & $\begin{array}{l}\text { Tambah benang, } \\
\text { harga turun. }\end{array}$ & Sesenggak \\
\hline 2 & $\begin{array}{l}\text { nyebit taliné } \\
\text { amis kacenikan } \\
\text { (Sanggra, }\end{array}$ & $\begin{array}{l}\text { Dalam menye- } \\
\text { pih tali, bagian } \\
\text { kecil selalu } \\
\text { kalah oleh yang }\end{array}$ & Sesawangan \\
lebih besar. & \\
\hline 3 & $\begin{array}{l}\text { Induk ayam ke- } \\
\text { panginané ké- } \\
\text { calan pitik } \\
\text { (Sanggra, } \\
\text { 2004:29) }\end{array}$ & $\begin{array}{l}\text { Sesawangan, } \\
\text { hilangan anak. }\end{array}$ & sesonggan \\
& &
\end{tabular}

\begin{tabular}{|c|c|c|c|}
\hline 4 & $\begin{array}{l}\text { depang lemeté } \\
\text { gisi, tusing ada } \\
\text { lemeté elung } \\
\text { (Sanggra, } \\
\text { 2004:31) }\end{array}$ & $\begin{array}{l}\text { Sikap fleksibel } \\
\text { tak mudah pa- } \\
\text { tah, tak mudah } \\
\text { kalah. }\end{array}$ & Seloka \\
\hline 5 & $\begin{array}{l}\text { Nyupraba Dutha } \\
\text { (Sanggra, } \\
2004: 48 \text { ) }\end{array}$ & $\begin{array}{l}\text { Déwi Supraba } \\
\text { jadi duta. }\end{array}$ & Sesonggan \\
\hline 6 & $\begin{array}{l}\text { kadi gedahé } \\
\text { pantigang } \\
\text { (Sanggra, } \\
\text { 2004:48) }\end{array}$ & $\begin{array}{l}\text { Hati hancur } \\
\text { remuk-re- } \\
\text { dam seperti } \\
\text { lampu-gelas } \\
\text { dibanting. }\end{array}$ & Sesawangan \\
\hline 7 & $\begin{array}{l}\text { lahru kangkang } \\
\text { tinibanin udan } \\
\text { sawengi (Suarsa, } \\
\text { 2009:23) }\end{array}$ & $\begin{array}{l}\text { kemarau pan- } \\
\text { jang, ditimpa } \\
\text { hujan sehari } \\
\text { semalam. }\end{array}$ & Sesawangan \\
\hline 8 & $\begin{array}{l}\text { clebingkah batan } \\
\text { biu, belahan } \\
\text { pané belahan } \\
\text { paso } \\
\text { (Suarsa, } \\
\text { 2009:72) }\end{array}$ & $\begin{array}{l}\text { Belahan batu di } \\
\text { bawah pohon } \\
\text { pisang, pecahan } \\
\text { pané pecahan } \\
\text { paso. }\end{array}$ & Peparikan \\
\hline 9 & $\begin{array}{l}\text { kadi siap sambe- } \\
\text { hin jagung (Suar- } \\
\text { sa, 2009:72) }\end{array}$ & $\begin{array}{l}\text { Bagaikan } \\
\text { kumpulan ayam } \\
\text { ditaburi jagung. }\end{array}$ & $\begin{array}{l}\text { Sesenggak, } \\
\text { sesawangan }\end{array}$ \\
\hline 10 & $\begin{array}{l}\text { mati mahapraw- } \\
\text { iréng rana (Suar- } \\
\text { sa, 2009:73). }\end{array}$ & $\begin{array}{l}\text { Tewasnya } \\
\text { seorang prajurit, } \\
\text { memang harus- } \\
\text { nya di medan } \\
\text { perang. }\end{array}$ & Seloka \\
\hline 11 & $\begin{array}{l}\text { stri ngarania, } \\
\text { apuy pada- } \\
\text { nia (Suarsa, } \\
\text { 2009:84) }\end{array}$ & $\begin{array}{l}\text { Wanita naman- } \\
\text { ya, api persa- } \\
\text { maannya. }\end{array}$ & Seloka \\
\hline 12 & $\begin{array}{l}\text { kadi gedahé } \\
\text { labuh ring } \\
\text { batu (Suarsa, } \\
\text { 2009:107) }\end{array}$ & $\begin{array}{l}\text { Seperti lam- } \\
\text { pu-gelas jatuh } \\
\text { di batu. }\end{array}$ & Sesawangan \\
\hline 13 & $\begin{array}{l}\text { kadi togogé } \\
\text { lolohin } \\
\text { (Suarsa, } \\
\text { 2009:117) }\end{array}$ & $\begin{array}{l}\text { seperti patung } \\
\text { diminumi jamu }\end{array}$ & $\begin{array}{l}\text { Sesawangan, } \\
\text { sesenggak }\end{array}$ \\
\hline 14 & $\begin{array}{l}\text { guruné jani suba } \\
\text { sayan guyu tur } \\
\text { sayan luyu } \\
\text { (Rida, 2014:2) }\end{array}$ & $\begin{array}{l}\text { Guru-guru } \\
\text { sekarang makin } \\
\text { tidak serius dan } \\
\text { makin santai. }\end{array}$ & Sesimbing \\
\hline
\end{tabular}




\begin{tabular}{|c|c|c|c|c|c|c|c|}
\hline 15 & $\begin{array}{l}\text { jelé melahé mula } \\
\text { masanding } \\
\text { (Rida, 2014:3) }\end{array}$ & $\begin{array}{l}\text { Buruk dan baik } \\
\text { tidak dapat } \\
\text { dipisahkan. }\end{array}$ & Sesonggan & 22 & \multirow{2}{*}{$\begin{array}{l}\text { pilih-pilih bekul } \\
\text { nyanan maan } \\
\text { buah bangiang } \\
\text { (Santha, } \\
\text { 2015:13) }\end{array}$} & \multirow{2}{*}{$\begin{array}{l}\text { Manya pilih } \\
\text { buah bekul, } \\
\text { malah mendapat } \\
\text { buah bangiang. }\end{array}$} & \multirow[t]{2}{*}{ Sesonggan } \\
\hline \multirow[t]{2}{*}{16} & aduk sera aji & Sesuatu yang & Sesimbing & & & & \\
\hline & $\begin{array}{l}\text { kéténg } \\
\text { (Rida, 2014:4) }\end{array}$ & $\begin{array}{l}\text { besar dan } \\
\text { mahal, dirusak } \\
\text { oleh sesuatu } \\
\text { yang kecil dan } \\
\text { harganya tidak } \\
\text { seberapa. }\end{array}$ & & \multirow[t]{2}{*}{23} & \multirow[t]{2}{*}{$\begin{array}{l}5 \mathrm{M} ; \text { madat, } \\
\text { memunyah, ma- } \\
\text { motoh, mamitra, } \\
\text { lan maling } \\
\text { (Santha, } \\
\text { 2015:27) }\end{array}$} & \multirow[t]{2}{*}{$\begin{array}{l}\text { "5 M: madat, } \\
\text { mabuk, berjudi, } \\
\text { selingkuh, dan } \\
\text { mencuri" }\end{array}$} & \multirow[t]{2}{*}{ Seloka } \\
\hline \multirow[b]{2}{*}{17} & & & & & & & \\
\hline & $\begin{array}{l}\text { tan bina kadi } \\
\text { togogé tance- } \\
\text { bang } \\
\text { (Rida, 2014:11) }\end{array}$ & $\begin{array}{l}\text { Tidak ada } \\
\text { bedanya dengan } \\
\text { patung yang } \\
\text { ditancapkan. }\end{array}$ & $\begin{array}{l}\text { Sesawangan, } \\
\text { sesenggak }\end{array}$ & \multirow[t]{2}{*}{24} & \multirow{2}{*}{$\begin{array}{l}\text { sing nyidang } \\
\text { maklépésan, } \\
\text { negak nogog } \\
\text { cara arca batu } \\
\text { (Santha,2015:29) }\end{array}$} & \multirow{2}{*}{$\begin{array}{l}\text { Tidak bisa ber- } \\
\text { buat apa-apa, } \\
\text { duduk diam } \\
\text { bagaikan patung } \\
\text { batu. }\end{array}$} & \multirow[t]{2}{*}{ Sesawangan } \\
\hline \multirow[t]{2}{*}{18} & \multirow{2}{*}{$\begin{array}{l}\text { gilik saguluk, } \\
\text { salunglung } \\
\text { sabayantaka } \\
\text { (Rida, 2014:74) }\end{array}$} & \multirow{2}{*}{$\begin{array}{l}\text { Selalu bersatu } \\
\text { padu dalam } \\
\text { suka dan duka. }\end{array}$} & \multirow[t]{2}{*}{ Sesonggan } & & & & \\
\hline & & & & \multirow[t]{2}{*}{25} & \multirow{2}{*}{$\begin{array}{l}\text { mirib patapan } \\
\text { arca batune } \\
\text { tondén putus } \\
\text { (Santha,2015:30) }\end{array}$} & \multirow{2}{*}{$\begin{array}{l}\text { Rupanya seperti } \\
\text { yoga patung } \\
\text { batu, belum } \\
\text { tuntas. }\end{array}$} & \multirow[t]{2}{*}{ Sesawangan } \\
\hline \multirow[t]{3}{*}{19} & \multirow{3}{*}{$\begin{array}{l}\text { wadahé wantah } \\
\text { agayung cam- } \\
\text { plung, yadiastun } \\
\text { ring segara sile- } \\
\text { mang, nanging } \\
\text { pikolihané wan- } \\
\text { tah acamplung, } \\
\text { tan lintangan. } \\
\text { (Rida, 2014:99) }\end{array}$} & \multirow{3}{*}{$\begin{array}{l}\text { Tempatnya } \\
\text { hanya se- } \\
\text { buah gayung } \\
\text { kecil dari buah } \\
\text { camplung, } \\
\text { walaupun } \\
\text { dicelupkan di } \\
\text { lautan, air yang } \\
\text { bisa ditam- } \\
\text { pung hanyalah } \\
\text { sebatas buah } \\
\text { camplung itu, } \\
\text { tidak mungkin } \\
\text { bisa lebih. }\end{array}$} & \multirow[t]{3}{*}{ Sesonggan } & & & & \\
\hline & & & & 26 & $\begin{array}{l}\text { bawang payané } \\
\text { kara jukuté, } \\
\text { tawang dayané } \\
\text { ketara unduké } \\
\text { (Santha,2015:57) }\end{array}$ & $\begin{array}{l}\text { Bawang, peria, } \\
\text { kacang kara } \\
\text { sayurnya, } \\
\text { ketahuan bo- } \\
\text { hong ketahuan } \\
\text { kisahnya..." }\end{array}$ & Peparikan \\
\hline & & & & 27 & $\begin{array}{l}\text { majukut di natah, } \\
\text { babar lélor } \\
\text { (San- } \\
\text { tha,2015:112) }\end{array}$ & $\begin{array}{l}\text { "bagaikan po- } \\
\text { hon sayuran di } \\
\text { halaman rumah, } \\
\text { pohon kélor, } \\
\text { amat terpesona" }\end{array}$ & Bladbadan \\
\hline \multirow[t]{2}{*}{20} & \multirow[t]{2}{*}{$\begin{array}{l}\text { ajak makejang } \\
\text { masih lakar } \\
\text { mulih ka karang } \\
\text { wayah, maluan } \\
\text { tekén durian } \\
\text { (Rida, 2014:119) }\end{array}$} & \multirow[t]{2}{*}{$\begin{array}{l}\text { Semua manusia } \\
\text { akan mati, } \\
\text { duluan atau } \\
\text { belakangan. }\end{array}$} & \multirow[t]{2}{*}{ Sesawangan } & \multirow[t]{2}{*}{28} & $\begin{array}{l}\text { pamuputné buyar } \\
\text { kadi gedahé } \\
\text { pantigang } \\
\text { (San- } \\
\text { tha,2015:128) }\end{array}$ & $\begin{array}{l}\text { Akhirnya han- } \\
\text { cur lebur seperti } \\
\text { barang pecah } \\
\text { belah diban- } \\
\text { ting..." }\end{array}$ & $\begin{array}{l}\text { Sesawangan, } \\
\text { sesenggakan }\end{array}$ \\
\hline & & & & & & & \\
\hline \multirow[t]{3}{*}{21} & \multirow{3}{*}{$\begin{array}{l}\text { Ané malaksana } \\
\text { melah sinah lakar } \\
\text { nepukin rahayu, } \\
\text { ané malaksana } \\
\text { jelé pedas lakar } \\
\text { nepukin ala } \\
\text { (Rida, 2014:125) }\end{array}$} & \multirow{3}{*}{$\begin{array}{l}\text { Siapa yang ber- } \\
\text { buat baik pasti } \\
\text { akan mendapat } \\
\text { pahala yang } \\
\text { baik, yang ber- } \\
\text { buat tidak baik } \\
\text { akan menerima } \\
\text { pahala yang } \\
\text { tidak baik. }\end{array}$} & \multirow[t]{3}{*}{ Sesimbing } & 29 & $\begin{array}{l}\text { kadi layangan } \\
\text { pegat } \\
\text { (San- } \\
\text { tha,2015:128) }\end{array}$ & $\begin{array}{l}\text { Bagaikan } \\
\text { laying-layang } \\
\text { putus talinya. }\end{array}$ & $\begin{array}{l}\text { Sesawangan, } \\
\text { sesenggakan }\end{array}$ \\
\hline & & & & 30 & $\begin{array}{l}\text { masih padidi cara } \\
\text { batun buluan } \\
\text { (San- } \\
\text { tha,2015:130) }\end{array}$ & $\begin{array}{l}\text { Tetap sendiri } \\
\text { seperti biji } \\
\text { rambutan. }\end{array}$ & $\begin{array}{l}\text { Sesenggakan, } \\
\text { Bladbadan }\end{array}$ \\
\hline & & & & 31 & $\begin{array}{l}\text { Madon jaka... } \\
\text { (San- } \\
\text { tha,2015:141) }\end{array}$ & $\begin{array}{l}\text { Nama lain daun } \\
\text { enau adalah } \\
\text { ron, artinya } \\
\text { 'makaronan' }\end{array}$ & Bladbadan \\
\hline
\end{tabular}




\begin{tabular}{ccl}
\hline ciplak-ciplak & Mengunyah & Sesawangan/ \\
cara cupak & makanan den- & Pepindan \\
(Timuhun, & gan cepak-ce- & \\
2015:14) & pak di mulut & \\
& seperti tokoh & \\
& Cupak (yang & \\
& doyan makan) & \\
\hline
\end{tabular}

33 cara padi, ngan- Seperti ilmu Sesenggakan can misi ngancan padi, kian berisi

jelih, ngancan kian merunduk

lengkong nguntul

(Timuhun,

2015:19)

\begin{tabular}{|c|c|c|c|}
\hline 34 & $\begin{array}{l}\text { cara barong pan- } \\
\text { ingalané nelik } \\
\text { sing makijapan } \\
\text { (Timuhun, 2015: } \\
\text { 39) }\end{array}$ & $\begin{array}{l}\text { Seperti barong, } \\
\text { matanya } \\
\text { terbelalak tak } \\
\text { berkedip }\end{array}$ & Sesawangan \\
\hline 35 & $\begin{array}{l}\text { Jaja godoh } \\
\text { mawadah beruk, } \\
\text { yén jodoh sinah } \\
\text { tepuk } \\
\text { (Timuhun, } \\
\text { 2015:42) }\end{array}$ & $\begin{array}{l}\text { Pisang goring } \\
\text { (jaja godoh) di } \\
\text { dalam beruk, } \\
\text { kalau jodoh } \\
\text { pasti ketemu. }\end{array}$ & Wewangsalan \\
\hline
\end{tabular}

36 kéweh nekepin Seperti pepatah, Sesenggakan

andus, sukeh takkan bisa

ngengkebang menutup asap,

bon bangké. takan bisa

(Timuhun, 2015: menutup bau

79) bangkai.

\begin{tabular}{|c|c|c|c|}
\hline 37 & $\begin{array}{l}\text { pekak ceningé } \\
\text { ngalahin luas } \\
\text { mulih ka karang } \\
\text { wayah } \\
\text { (Timuhun, } \\
\text { 2015:101) }\end{array}$ & $\begin{array}{l}\text { Kakek kamu } \\
\text { meninggalkan } \\
\text { kamu pergi ke } \\
\text { alam baka }\end{array}$ & $\begin{array}{l}\text { Sesawangan, } \\
\text { Pepindan }\end{array}$ \\
\hline
\end{tabular}

\begin{tabular}{|c|c|c|c|}
\hline 38 & $\begin{array}{l}\text { Musuh ané pal- } \\
\text { ing gedéna ento } \\
\text { musuh di awak } \\
\text { i raga padidi } \\
\text { Ning. } \\
\text { (Timuhun, } \\
\text { 2015:102-3) }\end{array}$ & $\begin{array}{l}\text { Sesungguhnya } \\
\text { musuh yang } \\
\text { paling hebat } \\
\text { adalah justru } \\
\text { musuh yang ada } \\
\text { di di dalam diri } \\
\text { kita sendiri. }\end{array}$ & Seloka \\
\hline 39 & $\begin{array}{l}\text { Mlajah tetepang, } \\
\text { krana sing lakar } \\
\text { telah-telah ané } \\
\text { patut plajahin! } \\
\text { (Timuhun, } \\
\text { 2015:116) }\end{array}$ & $\begin{array}{l}\text { Rajin dan tekun } \\
\text { belajar,karena } \\
\text { ilmu tak akan } \\
\text { habis-habisnya } \\
\text { dipelajari. }\end{array}$ & Seloka \\
\hline
\end{tabular}

\begin{tabular}{llll}
\hline 40 & $\begin{array}{l}\text { sambilang } \\
\text { mapalalian sam- } \\
\text { bilang malajah } \\
\text { (Timuhun, } \\
\text { 2015:118). }\end{array}$ & $\begin{array}{l}\text { Bermain sambil } \\
\text { belajar, belajar } \\
\text { sambil bermain. }\end{array}$ & Seloka \\
\hline 41 & $\begin{array}{l}\text { Sategeh langit nu } \\
\text { ada langit } \\
\text { (Timuhun, }\end{array}$ & $\begin{array}{l}\text { Di atas langit } \\
\text { masih ada } \\
\text { langit. }\end{array}$ & Seloka \\
& & & \\
42 & $\begin{array}{l}\text { Jaen idup di Bali } \\
\text { (Timuhun, }\end{array}$ & Enak hidup di & Sesimbing \\
2015:). & & \\
\hline
\end{tabular}

\section{IDENTIFIKASI DAN KLASIFIKASI KATA MUTIARA}

Bahasa Bali termasuk bahasa yang unik. Keunikan itu terlihat dari jumlah penuturnya yang relatif kecil, katakanlah sebanyak empat juta setara penduduk Bali, namun bahasa Bali memiliki sistem aksara (huruf Bali) dan memiliki tradisi sastra yang panjang, baik sastra tradisional Bali maupun sastra Bali modern. Belakangan, bahasa Bali juga menjadi media untuk lagu pop Bali. Sebagai bahasa dengan tradisi sastra dan bahasa medium seni pertunjukan, bahasa Bali kaya akan gaya bahasa (Ginarsa, 1980; Simpen, 1980; Tinggen, 1988). Tiap-tiap penulis mendata jumah peribahasa berbeda-beda, misalnya Ginarsa mendata ada sepuluh peribahasa, Simpen mendata sampai 18 jenis, sedangkan Tinggen sebanyak 13 jenis. Menurut Tinggen (1988) ungkapan atau peribahasa Bali bisa dibedakan menjadi tiga belas, yaitu cecimpedan (teka-teki), bladbadan (permainan bunyi, maknanya diplesetkan sesuai bunyi kata yang dipakai), raos ngempelin (kata mendua), sesawangan (perumpamaan), sesimbing (sindiran), seloka (bidal), sesenggakan (ibarat), sesonggan (pepatah), wewangsalan (tamsil, karmina), peparikan (pantun), tetingkesan (litotes), sesapan (sapaan), dan sesawen (tanda, simbol). Beberapa jenis peribahasa memiliki persamaan, seperti sesawangan yang berarti perumpamaan dengan pepindan dan sesenggak yang juga berarti perumpamaan. Satu jenis yang tidak muncul dalam kategori Tinggen tetapi muncul dalam kategori yang lain adalah cecangkikan yaitu sejenis cecimpedan mengandung unsur bergurau untuk menjebak.

\section{VARIASI UNGKAPAN}

Dari ungkapan yang ada, terdapat ungkapan sama yang bervariasi susunan katanya namun maknanya sama. Variasi itu menunjukkan kekayaan ungkapan, kreativitas penulis, dan fleksibilitas ungkapan dengan arti dan makna yang sama. Misalnya, ungkapan yang berbentuk sesawangan (perumpamaan) 'buyar kadi gedahé pantigang' (buyar bagai gedah dibanting) memiliki beberapa variasi. Gedah adalah lampu minyak tanah yang penampung 
minyaknya berbahan gelas yang mudah pecah berkeping jika jatuh apalagi dibanting. Ada pun variasi tekstualnya adalah 'kadi gedahé labuh ring batu' (ibarat gedah jatuh di batu). Kedua ungkapan ini menggunakan kata kunci 'gedah', yang satu divariasikan dengan 'gedah dibanting', yang satu lagi 'gedah' jatuh di batu. Ungkapan pertama seperti dilakukan secara sengaja, bahwa gedah dibanting (entah ke batu atau tempat keras lainnya), sedangkan ungkapan kedua bersifat 'tidak sengaja', karena labuh atau 'jatuh' adalah insiden yang tidak dapat dihindarkan, bukan kesengajaan.

Kedua ungkapan itu digunakan untuk melukiskan perasaan yang sedih dan hancur berkeping-keping seperti kepingan gelas (gedah). Dalam cerita Ketemu ring Tampaksiring, kesedihan tokoh cerita, Luh Kompyang, dilukiskan hancur berkeping karena ditinggalkan suaminya saat hamil. Ungkapan dengan gedah ada tiga variasi dan ketiganya digunakan pengarang untuk melukiskan kesedihan. Penggunaan ungkapan itu membuat ekspresi kesedihan dapat terungkap dengan akurat. Tanpa ungkapan ini, intensitas kesedihan mungkin kurang bisa dituturkan dengan efektif. Dalam percakapan sehari-hari, penggunaaan perumpamaan seperti ini juga sangat efektif untuk melukiskan perasaan kesedihan yang dalam.

Perumpamaan merupakan ungkapan penting dalam pemakaian bahasa sehari-hari. Perumpamaan dapat menjadi ungkapan pengganti untuk menegaskan makna kata yang hendak disampaikan. Ada perumpamaan yang unik Bali, ada juga ungkapan yang sama bisa ditemukan dalam bahasa Indonesia. Hanya saja susunan katanya berbeda. Terkadang makna ungkapan digunakan secara berbeda juga. Perbedaan itu bersifat kontekstual. Secara logika, perbedaan makna itu juga bisa diterima, tergantung cara memandang.

\section{INTERTEKSTUALITAS EKSPRESI KEARIFAN LOKAL}

Ungkapan yang terdapat dalam sastra Bali modern terkadang berasal dari karya sastra tradisional atau kitab-kitab agama, seperti ungkapan 'eda ngaden awak bisa' (jangan menganggap diri bisa) dalam Geguritan Basur atau 'paras paropa sarpana ya yang artinya ('rela tolong-menolong sesama manusia') yang terdapat dalam Kekawin Ramayana, atau ungkapan 'karang awake tandurin' atau 'nandurin karang awak' ('bertani dalam raga sendiri' atau 'meningkatkan potensi diri') yang terdapat dalam Geguritan Salampah Laku karya Ida Pedanda Made Sidemen. Ada juga ungkapan yang berasal dari ungkapan yang populer di masyarakat seeprti tampak dalam lagu pop Bali (Turaeni 2017). Fakta ini menunjukkan bahwa ungkapan dalam bahasa Bali bersifat intertekstual. Hubungan interteks juga tampak implisit dengan bahasa Indonesia. Artinya, ungkapan kearifan lokal Bali, memiliki sinonim dalam bahasa Indonesia.
Dalam antologi cerita pendek Gede Ombak Gede Angin karya Made Suarsa terdapat cerpen berjudul Lahru Kangkang Tinibanin Uudan Sawengi (panas setahun disiram hujan semalam) mengingatkan pada pepatah dalam bahasa Indonesia "Kemarau setahun dihapuskan hujan sehari". Dalam bahasa Indonesia, pepatah ini biasanya diberikan arti 'kebaikan yang banyak dihapuskan oleh kejahatan yang sedikit (kebaikan yang panjang dihapus dengan kejelekan yang pendek). Dalam cerpen bahasa Bali, maknanya justru sebaliknya, yaitu perasaan rindu yang lama akhirnya dibayar dengan suka-cita sehari. Seperti diuraikan di dalam tabel di atas, tokoh Luh Suasti dalam cerpen Lahru Kangkang Tinibanin Udan Sawengi, sangat hancur hatinya, karena berbulan-bulan ditinggal suaminya pergi karena merasa tidak cocok dengan nenek Luh Suasti. Sekonyong-konyong suaminya datang tengah malam, dan berbahagia melakukan hubungan suami istri sampai pagi. Jadi, kesepian Luh Suasti berbulan-bulan, terhapus oleh persenggamaan semalam suntuk.

Ungkapan lain yang mendapat konteks berbeda dari kelaziman adalah 'sategeh langit nu ada langit', yang dalam bahasa Indonesia sepadan dengan peribahasa 'di atas langit masih ada langit'. Artinya, orang tidak boleh sombong, tidak boleh merasa diri pintar, karena pasti ada orang yang lebih pintar daripada kita. Dalam konteks cerita 'Jaen Idup di Bali' dalam antologi karya Suar Timuhun ungkapan 'sategeh langit nu ada langit' digunakan pengarang untuk memberikan nasehat jangan bersifat iri hati. Kalau melihat ke atas, kita akan selalu merasa kekurangan, akhirnya timbul rasa tidak puas, tidak senang melihat orang bahagia. Saran lainnya adalah bahwa orang yang hidup menderita, di bawah kita banyak juga jumlahnya. Disarankan agar kita selalu ingat dengan hukum karma (karma phala). Kalau dalam bahasa Indonesia ungkapan diarahkan untuk mengatakan bahwa di atas kita pasti ada orang yang lebih 'pintar', dalam konteks cerita digunakan untuk melukiskan 'di atas kita selalu ada orang yang lebih berada, kaya, bahagia'. Pesannya dua, pertama jangan pernah merasa iri pada mereka yang bahagia, kaya, melebihi kita; kedua, lihatlah ke bawah, banyak yang lebih menderita daripada kita. Walaupun makna dan konteks yang diberikan berbeda, esensinya sama, bahwa ungkapan 'sategeh langit enu ada langit' adalah untuk introspeksi.

Keragaman, variasi, perbedaan makna ungkapan tidak perlu membuat kira bingung bahwa tidak ada kepastian. Makna kata atau ungkapan selalu jamak, multitafsir, semua ditentukan oleh konteksnya. Perbedaan tafsir itu sebaiknya diterima sebagai keragaman, kekayaan, dan keniscayaan. Ungkapan adalah bagian dari tradisi lisan. Tradisi lisan ditandai dengan variasi yang kaya. Penggunaan ungkapan dalam karya sastra bisa memberikan variasi ungkapan dan kekayaan penafsiran. Pemakaiannya dan pemaknaannya tergantung dalam dua konteks: konteks tekstual dan konteks sosial. Perbedaan atau persamaan dalam dua konteks itu adalah keniscayaan yang membuat ungkapan-ungka- 
pan menjadi kaya, variatif, dan tetap mempertahankan makna esensinya.

Ungkapan panginané kécalan pitik ['induk ayam kehilangan anak'] (Sanggra, 2004:29) merupakan ungkapan yang memiliki hubungan intertekstualitas dengan peribabasa Indonesia yang berbunyi 'seperti anak ayam kehilangan induk'. Jika dibandingkan, isinya mengandung paradoks, di mana dalam ungkapan Indonesia yang ‘kehilangan' adalah 'anak ayam', sedangkan dalam bahasa Bali yang kehilangan adalah 'induk ayam'. Dari segi logika, keduanya benar dan kedua situasi bsia terjadi yang akibatnya sama saja. Induk ayam kehilangan anaknya juga merasa bingung, sedangkan anak ayam kehilangan induknya juga bingung. Dalam konteks Ketemu ring Tampaksiring, peristiwa itu terjadi dalam mimpi Mén Rawit dalam cerpen "Sekar Emas". Mén Rawit bermimpi, anaknya diterjang arus sungai ketika menggali pasir. Mén Rawit sangat bingung lari ke sana-kemari karena bingung tak tahu apa yang harus dikerjakan, bagaikan induk ayam kebingungan kehilangan anak-anaknya. Kalau selama ini kita terbiasa mendengarkan ungkapan 'anak ayam kehilangan induk', dalam bahasa Bali ungkapan sangat berbeda yaitu 'induk ayam kehilangan anak', sama saja sedihnya. Di dalam sastra, penggunaan ungkapan yang berbeda ini adalah kreativitas. Perumpamaan yang populer dalam bahasa Bali adalah 'cara padi, ngancan misi ngancan jelih, ngancan lengkong nguntul' (Timuhun, 2015:19), artinya 'seperti padi, makin berisi makin merunduk', maknanya 'menjadi orang tidak perlu sombong' atau 'orang yang merunduk belum tentu bodoh'. Dalam peribahasa Bali, wacana tersebut termasuk kategori sesenggakan (ibarat atau perumpamaan), yakni perumpamaan orang yang pintar dengan mengambil perbandingan dengan buah padi. Buah padi itu, makin berisi makin merunduk. Demikian juga orang yang pintar, makin pintar, makin kalem dan tidak banyak tingkah. Dalam konteks cerita, ungkapan itu adalah nasihat dari tokoh Pan Budi (ayah Budi) dalam cerpen "Tutur" kepada Wayan Budi sembari menunjuk ke arah hamparan padi menguning yang siap dipanen, supaya kelak Wayan Budi bersikap seperti padi, yang selalu rendah hati walaupun merasa sudah pintar. Konteks tekstual dan konteks sosial ungkapan ini tidak jauh berbeda. Dalam masyarakat pun, pesan dari perumpamaan 'seperti padi, makin berisi makin merunduk' dimaksudkan untuk menyampaikan nasehat agar orang tidak sombong, tidak merasa bisa. Makna ungkapan ini mirip atau searah dengan ungkapan 'eda ngaden awak bisa' atau 'setegeh langit nu ada langit'.

Ungkapan populer lainnya yang terdapat dalam cerpen "Tato" (Timuhun, 2015:79) adalah 'kéweh nekepin andus, sukeh ngengkebang bon bangké' yang artinya 'tidak mungkin menutupi asap, sulit menyembunyikan bau mayat'. Yang menarik dalam cerpen ini adalah penulisan ungkapan tersebut yang diisi dengan kata 'sesenggaké', berarti bahwa ungkapan ini adalah 'sesenggak' atau 'perumpamaan' (ibarat). Secara umum wacana itu bermakna bahwa tidak akan mampu menyembunyikan kejahatan atau kesalahan. Suatu saat, cepat atau lambat, pasti akan ketahuan juga. Dalam konteks cerpen "Tato", wacana tersebut merupakan pernyataan penyesalan yang diucapkan oleh Wayan Tara. Wayan Tara mengucapkan penyesalan itu sebagai sebuah insiden dalam cerpen "Tato", menjawab pertanyaan ayahnya mengapa ia diberhentikan bekerja di hotel. Lataran tiga hari sebelumnya ia mentato lengannya. Karena manajer, lalu ia diperintahkan untuk mengundurkan diri dengan kesadaran sendiri, kalau tidak mau dipecat. Ketidakmampuannya menyembunyikan tato kecil di lengannnya itulah yang diibaratkan kéweh nekepin andus, sukeh ngengkebang bon bangké (sulit menutupi asap adan menutupi bau bangkai). Ungkapan ini masih banyak dipakai dalam percakapan sehari-hari, sebagai pemanis ungkapan dan mempertegas inti pembicaraan.

\section{KONTEKS TESKTUAL DAN KONTEKSTUAL UNGKAPAN 'JAEN IDUP DI BALI'}

Rangkaian kata-kata 'jaen idup di Bali' merupakan ungkapan yang relatif baru di Bali. Ungkapan ini baru populer sekitar tahun 2015, ketika cerpen ini ditulis. Ungkapan ini secara sosial muncul ketika semakin dirasakan banyak migran datang ke Bali sejalan dengan kemajuan pariwisata. Orang datang ke Bali karena di Bali mudah mencari pekerjaan. Peluang kerja banyak asal mau bekerja keras. Pendek kata, hidup di Bali itu enak. Ungkapan ini juga untuk menyindir orang Bali yang malas bekerja karena terlalu manja dalam menikmati hidup enak di Bali.

Ungkapan ini merupakan sesimbing (sindiran) karena makna yang disampaikan kebalikan dengan isi ungkapan. Dalam cerita berjudul 'Jaen Idup di Bali' dilukiskan aspek yang membuat orang hidup enak di Bali dan juga faktor yang membuat orang merasa tidak enak hidup di Bali. Dalam konteks cerita, dikisahkan bagaimana seorang remaja Bali yang berada di daerah perantauan di Kalimantan ingin sekali hidup di Bali. Ayahnya seorang transmigran Bali yang terpaksa bertransmigrasi karena sakit. Saat sakit, tidak ada dokter dan dukun yang membantun menyembuhkan. Dukun mengatakan bahwa dia kena serangan black magic sehingga harus pergi dari Bali. Hal itu dituturkan sang ayah Made Pica kepada anaknya Putu Bagia dan kadek Laksmi. Pesan cerita adalah bahwa hidup di Bali bisa enak kalau tidak diserang leak dan sikap iri hati.

Makna ungkapan 'jaen idup di Bali' tidaklah tunggal, tetapi beragam. Jika dicek di internet makna dan penggunaan ungkapan itu, kita akan bertemu dengan berbagai makna, Misalnya, seperti ini:

"JAEN IDUP DI BALI or ENAK HIDUP DI BALI" apabila lingkunganmu bersih, keamanan terjamin, tidak ada pengangguran, infrastruktur jalan mantap, kesehatan terjamin, kemiskinan dapat dientaskan, toleransi antar umat terjalin dengan baik dan masih banyak lagi. Yang terpenting itu semua untuk mewujudkan masyarakat yang da- 
mai, makmur dan sejahtera, sehingga 'jaen idup di bali' akan menjadi Nyata. Jadikan dirimu sebagai bagian untuk mewujudkan semua itu mulai dari peduli dengan lingkungan disekitarmu.

(sumber: https://deeajuz.wordpress.com/2015/09/06/jaenidup-di-bali/)

Dalam kuitpan tulisan di atas, makna 'jaen idup di Bali' diarahkan ke masalah lingkungan, keamanan, infrastruktur, kesehatan, kebersihan, dan toleransi. Pesannya adalah agar orang peduli terhadap 'lingkungan di sekitar', tentu saja maksudnya adalah lingkungan alam (kebersihan, kesehatan). Di sini 'jaen idup di Bali' tidak berkaitan dengan rasa isi atau black magic atau ilmu hitam.

Contoh lain mengenai pemaknaan sosial 'jaen idup di Bali' adalah ketika dijadikan inspirasi lagu pop Bali oleh sebuah band dari Gianyar, Band 703, tahun 2016, setahun setelah cerpen tertulis. Dalam syair lagunya tertulis pemaknaan ungkapan 'jaen idup di Bali' seperti ini: (sepantasnya sesama saudara saling menolong). Sampai di sini, ungkapan 'jaen idup di Bali' tidak ada menjelaskan apa baiknya atau apa enaknya hidup di Bali. Di dalam cerpen, aspek 'enak' dan 'baik' hidup di Bali dijelaskan karena Bali merupakan daerah wisata yang mengagumkan, yang memiliki seni budaya dan alam yang indah tiada tandingannnya.

Sebagai petutup kajian konteks sosial kata-kata mutiara dalam cerpen sastra Bali modern dapat dikatakan bahwa ungkapan kata-kata mutiara itu bersifat intertekstual. Kehadirannya dalam teks sastra Bali diawali dengan kehadirannya dalam tradisi lisan atau teks sastra lainnya. Ada juga ungkapan berasal dari masyarakat, lalu ditulis di dalam sastra, kemudian menjadi judul dan tema lagu. Berbagai contoh di atas menunjukkan intertekstualitas dengan teks sastra Bali lainnya seperti Niti Sastra dan Kakawin Ramayana dan juga dengan peribahasa bahasa Indonesia. Ungkapan dalam peribahasa Bali memiliki susunan kata

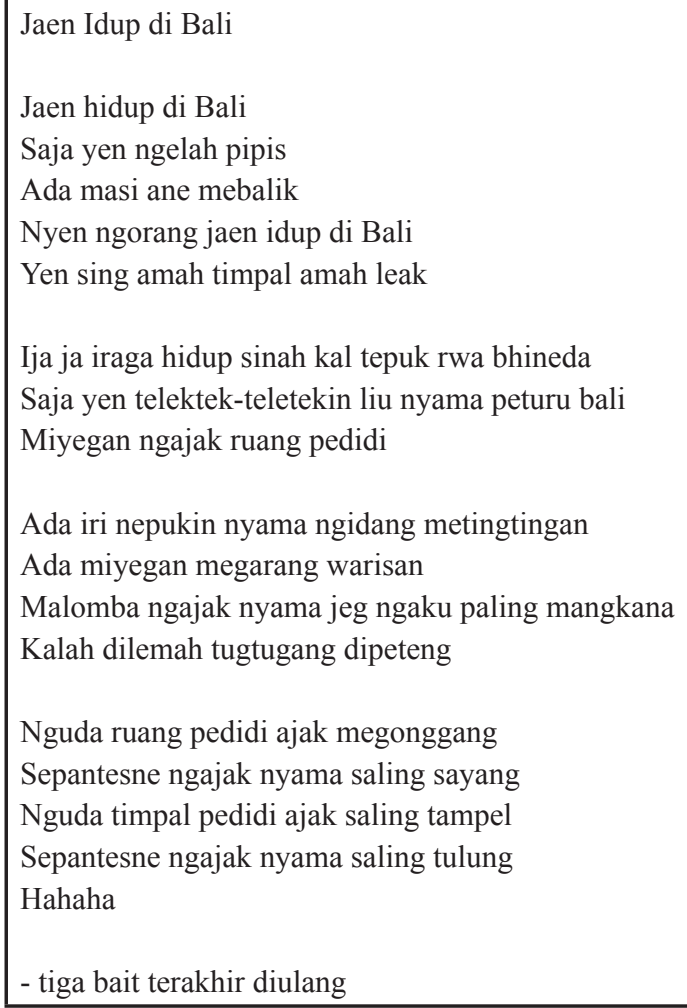

Enak Hidup di Bali

Enak hidup di Bali

Benar jika punya uang

Ada juga yang tak setuju

Siapa bilang hidup di Bali enak

Jika tak dimakan teman, dimakan leak

Di mana pun hidup, pasti ketemu baik-buruk

Benar jika diperhatikan banyak teman sesama Bali

Bertengkar dengan warga sendiri

Ada yang iri melihat yang mampu

Ada yang bertengkar rebutan warisan

Berlomba dengan sesama ngaku paling hebat

Kalau siang, lanjutin malam

Mengapa warga sesama diajak bertengkar

Mestinya sesame warga saling sayang

Mengapa warga sendiri diajak saling pukul

Mestinya sesama warga tolong-menolong

Haaaaa

Sumber: http://www.liriklagubali.com/2016/05/lirik-lagu-bali-tut-susana-jaen-idup-di-bali.html

Akses: 21 Oktober 2018

Ada beberapa pesan dalam lagu tersebut. Di bait awal ada ungkapan yang maknanya sama dengan yang tersirat dan tersurat dalam cerpen 'Yen sing amah timpal amah leak' (kalau tidak dimangsa kawan, dimangsa leak). Pesan lagu berlanjut ke masalah sindiran mengenai mengapa orang Bali suka berkelahi dengan saudara. Inilah makna sesimbing ungkapan ini. Lagu tidak saja berisi sindiran, tetpai juga saran, yaitu 'Sepantesne ngajak nyama saling tulung' dan makna tekstual dan konteks sosial yang dinamis dengan esensi makna tetap atau bervariasi. Ungkapan 'jaen idup di Bali' yang populer dalam tiga tahun terakhir ini memiliki makna konteks-sosial berbeda-beda namun esensinya sama sebagai sindiran. 


\section{SIMPULAN}

Analisis di atas mengidentifikasi dan menunjukkan ungkapan-ungkapan kearifan lokal yang muncul dalam sastra Bali modern. Kini pembaca bisa merujuk dalam teks mana ungkapan peribahasa Bali itu terpakai, dengan demikian mereka akan dapat mengenal karya sastra yang memuatnya. Karena banyak ungkapan kearifan lokal itu merupakan bagian dari tradisi lisan, ketika teks sastra memuatnya, kelak rujukan tekstual bisa dilakukan.

Lebih jauh, dapat ditarik tiga simpulan. Pertama, karya sastra Bali modern yang dianalisis mengandung beragam bentuk kata-kata mutiara yang menunjukkan kreativitas pengarang dalam memakai, menciptakan, dan melestarikan kata mutiara dalam bahasa Bali. Berdasarkan identifikasi dan klasifikasi, terdapat tujuh jenis kata-kata mutiara yang terkandung di dalam lima kumpulan cerpen yang dikaji dalam penelitian ini yaitu sesonggan (pepatah), sesawangan (perumpamaan), seloka (bidal), wawangsalan, sesimbing, peparikan, dan bladbadan. Dari ketujuh bentuk kata-kata mutiara itu, bentuk yang paling banyak muncul adalah sesonggan atau pepatah seperti 'kadi togoge lolohin' (seperti patung disuguhkan minuman), 'kadi gedahe ulung di batu' (seperti lampu-gelas jatuh di batu, hancur berkeping), dan 'gede ombak gede angin' (ombak besar angin kencang). Banyaknya ungkapan kata mutiara berupa sesonggan terjadi karena karya sastra adalah ungkapan seni bahasa untuk menyampaikan sesuatu secara tidak langsung. Salah satu bentuk ungkapan yang paling lazim adalah sesonggan (pepatah). Ungkapan peribahasa dalam bahasa Bali bisa ditemukan dalam teks sastra lain dan juga dalam bahasa Indonesia. Hal ini menunjukkan bahwa ungkapan kata mutiara Bali berbasis kearifan lokal bersifat intertekstualitas.

Kedua, pemaknaan terhadap kata-kata mutiara secara tekstual berbeda-beda sesuai konteks cerita. Misalnya, ungkapan kadi gédahe ulung di batu' dalam cerpen Sujén Bétél, digunakan pengarang untuk melukiskan rasa duka mendalam seorang istri karena suaminya meninggal tiba-tiba. Ungkapan kesedihan hatinya hancur berkeping itu diumpamakan seperti lampu-gelas yang berkeping karena jatuih di batu. Ungkapan perumpamaan yang sama dengan lain susunan kata-kata 'buyar kadi gedahé pantigang...”, melukiskan hancurnya hati seorang lelaki ketika teman baiknya yang diberikan kepercayaan menjaga pacarnya akhirnya menikahi pacar tersebut. Konteks tekstual kedua ungkapan berbeda, yaitu dalam satu keluarga, dalam kontkes suami-istri, yang satu lagi dalam konteks persahabatan yang berdasarkan kepercayaan ternyata buyar karena satu orang melanggar kepercayaan. Meskipun konteks cerita berbeda-beda, perumpamaan tersebut memiliki makna yang sama yatiu untuk mengungkapkan hati yang hancur berkeping-keping, seperti lampu-gelas dibanting di batu. Perbedaan terjadi karena kreativitas pengarang yang kemudian menambah atau memperkaya konteks tekstual sebuah perumpamaan.

Ketiga, pemaknaan kontekstual kata-kata mutiara dalam karya sastra selaras dengan pemaknaan tekstual. Artinya, tidak ada perbedaan makna antara tekstual dan kontekstual. Yang terjadi adalah pengayaan makna yang maksud dan artinya masih dalam satu kluster makna. Ungkapan 'jaen idup di Bali'secara harfiah berarti 'enak hidup di Bali'. Ungkapan yang tanpa konteks itu bisa dikenakan pada berbagai konteks, misalnya 'enak hidup di Bali' karena di Bali mudah mencari pekerjaa, rezeki, atau karena di Bali aman tanpa gangguan yang berarti. Dalam cerita berjudul 'Jaen Idup di Bali', realitas enak hidup di Bali tidak dijelaskan secara eksplisit, tetapi sudah menjadi semacam mitos yang dipercaya banyak orang bahwa enak hidup di Bali. Yang ditekankan sebagai konteks cerita yang relevan sebagai konteks sosial adalah bahwa hidup di Bali itu enak kalau tidak punya musuh yang iri hati dan tidak kena serangan lèak (black magic). Jika kedua hal itu menyerang, mitos enak hidup di Bali sama sekali kosong, tidak benar. Pemaknaan ungkapan dalam konteks sosial diberikan ilustrasi yang berbeda-beda tetapi secara umum esensinya sama.

\section{UCAPAN TERIMA KASIH}

Artikel ini disusun berdasarkan penelitian yang didanai LPPM Universitas Udayana sekma riset HUPS (Hibah Unggulan program Studi) dengan kontrak nomor 109/UN14.2.1.II/LT/2018. Penulis menyampaikan terima kasih kepada Rektor Unud, Ketua LPPM Unud, Dekan FIB, dan Korprodi Sastra Indonesia Unud atas dukungannya.

\section{DAFTAR RUJUKAN}

Agastia, I.B.G. 1994. Ida Pedanda Made Sidemen Pengarang Besar Bali Abad ke-20. Denpasar: Yayasan Dharma Sastra.

Allen, Graham. 2000. Intertextuality. London: Routledge. Bagus, I Gusti Ngurah, dkk. 1978. Kembang Rampe Kasusastraan Bali. Singaraja: Balai Penelitian Bahasa Singaraja, Bali.

Bagus, I Gusti Ngurah, dkk. 1979/1980. Peribahasa dalam Bahasa Bali. Singaraja: FKIP Universitas Udayana.

Barthes, Roland. 1977. Image-Music-Text, Essays Selected and Translated by Stephen Heat. Glasgow: Fontana/Collin.

Eddy, Nyoman Tusthi. 1991. Mengenal Sastra Bali Modern. Jaakrta: Balai Pustaka.

Ginarsa, Ketut. 1980. Paribasa Bali. Singaraja: Balai Penelitian Bahasa Singaraja, Bali. 
Putra, I Nyoman Darma. 2010. Tonggak Baru Sastra Bali Modern. Denpasar: Pustaka Larasan.

Putra, I Nyoman Darma. 2013. "Hadiah Sastra Rancage: Pilar Penting Perkembangan Sastera Balio Modern", dalam Etti R.S. dkk. (eds) Seperempat Abad Hadiah Sastera Rancage, pp.47-59. Bandung: Yayasan Kebudayaan Rancage.

Putra, I Pt. Budiantara, I Kt. Paramarta, I Md. Sutama. 2016. "Basita Paribasa ring Album "Nasi Goreng Spesial" Kekawian Widi Widiana" e-Journal JPBB Universitas Pendidikan Ganesha, Volume 04 No. 02, pp. tanpa halaman.

Rida, I Ketut. 2014. Lawar Goak. Denpasar: Buku Arti. Sanggra, I Made. 2003. Ketemu ring Tampaksiring. Denpasar: Buku Arti.

Santha, IGG Djelantik. 2015. Kacunduk ring Besakih. Tabanan: Pustaka Ekspresi.

Simpen I Wayan. 1980. Basita Paribasa. Denpasar : Upada sastra

Suarsa, I Made. 2006. Gede Ombak Gede Angin. Denpasar: Fakultas Sastra Unud.

Tinggen, I Nengah. 1988. Aneka Rupa Paribasa Bali. Singaraja: Rhika Dewata.

Tryniecka, Aleksandra. 2014. "The Faces of Intertextuality in The Literary Analysis: A Reappraisal", International Journal of Arts \& Sciences, 07(04):153-159 (2014)

Turaeni, Ni Nyoman Tanjung. 2017. "Pengalihwahanaan Paribasa Bali Lisan ke dalam Lagu Bali Populer", Aksara, Vol. 29, No. 2, Desember 2017, pp. 211.224. 